Демченко Володимир Миколайович кандидат філологічних наук, доцент, доцент кафедри державного управління i місцевого самоврядування, Херсонський національний технічний університет, Бериславське Шосе, 24, м. Херсон, 73008, тел.: (050) 149-93-45, e-mail: d.vovchyk@gmail.com, https://orcid.org/0000-0003-1841-7798

\title{
ТЕРМІНОЛОГІЧНІ СТЕРЕОТИПИ ІДЕОЛОГІЧНОГО МАНІПУЛЮВАННЯ
}

Анотація. У статті розглядаються терміни «фашизм», «шовінізм», «імперіалізм», «соціалізм» у площині їх використання в ідеологічних схемах із метою маніпулювання маргінальними народними масами. Як джерело аналізу вибрано доповідь деспотичного лідера Радянського Союзу Йосифа Сталіна 6 листопада 1941 року, де використано технології такого маніпулювання. Розглянуто словникові дефініції терміна «фашизм» як найбільш актуального на сьогодні в площині умисного спотворення дійсності у протистоянні України та Росії. Визначено, що означені негативні терміни тісно пов'язані як похідні / результати самодержавного правління: тоталітарний режим - для зміцнення диктаторської влади, шовінізм - загарбання інших територій в ім'я своєї країни / нації, імперіалізм - утворення імперії, геноцид й етноцид - результат терористичного способу отримання влади.

Зроблено висновок, що зазначені термінологічні колізії, що виявляють хибні ідеологічні стереотипи, наявні через мотив, актуальний упродовж багатьох століть, - маніпулювання власним народом. Із боку Росії стосовно України таке маніпулювання відбувається через зворотне звинувачення в цьому політичного супротивника. У такому разі слова Сталіна про одурення німецькими ідеологами народу потрібно сприймати і як одурення підвладного йому народу. Зроблено риторичне спростування таких хибних ідеологічних звинувачень, у результаті чого українцям властиві демократичні пріоритети, а тому терміни «республіка», «унітарія», «ліберальність» стосовно держави Україна повною мірою відповідають своїй сутності. На відміну від цього терміни «радянський», «соціалістичний», «республіка», «союз», «федерація» стосовно колишньої імперії та сучасної Росії не відповідають своїй семантичній сутності, і в той же час актуальними в характеристиці означених державних формацій $\epsilon$ терміни «шовінізм» та «імперіалізм». Тобто в межах українського політичного дискурсу щодо антидержавного протистояння більш логічно називати відповідних осіб не «сепаратисти», а «імперіалісти». 
Ключові слова: фашизм, імперія, самодержавство, маніпулювання, Сталін, термін, Україна, Росія.

Demchenko Volodymyr Mykolayovych Candidate of Philological Sciences, Associate Professor, Associate Professor of Department of Public Administration and Local Self-Government, Kherson National Technical University, Beryslav Highway, 24, Kherson, 73008, тел.: (050) 149-93-45, e-mail: d.vovchyk@gmail.com, https://orcid.org/0000-0003-1841-7798

\section{TERMINOLOGICAL STEREOTYPES OF IDEOLOGICAL MANIPULATION}

Abstract. The article considers the terms «fascism», «chauvinism», «imperialism», «socialism» in terms of their use in ideological schemes in order to manipulate the marginal masses. The source of the analysis was the report by the despotic leader of the Soviet Union, Joseph Stalin, on November 6, 1941, which used the technology of such manipulation. The dictionary defines the term «fascism» as the most relevant today in terms of deliberate distortion of reality in the confrontation between Ukraine and Russia. It is determined that these negative terms are closely related as derivatives / results of autocratic rule: totalitarian regime - to strengthen dictatorial power, chauvinism - conquest of other territories in the name of their country / nation, imperialism - empire formation, genocide and ethnocide - the result of terrorist way to gain power.

It is concluded that these terminological conflicts, which reveal false ideological stereotypes that exist due to a motive that has been relevant for many centuries - the manipulation of their own people. Russia is manipulating Ukraine because of accusations of a political opponent. In this case, Stalin's words about the foolishness of the German ideologues of the people should be perceived as a foolishness of the people under his control. A rhetorical refutation of such false ideological accusations has been made, as a result of which Ukrainians have democratic priorities, and therefore the terms «republic», «unitarism», «liberalism» in relation to the state of Ukraine fully correspond to their semantic essence. In contrast, the terms «soviet», «socialist», «republic», «union», «federation» in relation to the former empire and modern Russia do not correspond to their essence, and at the same time relevant in the description of these state formations are the terms «chauvinism» and «imperialism». That is, within the framework of the Ukrainian political discourse on anti-state confrontation, it is more logical to call the relevant persons not «separatists» but «imperialists».

Keywords: fascism, empire, autocracy, manipulation, Stalin, term, Ukraine, Russia.

Постановка проблеми. У сучасній ситуації політичного й воєнного протистояння 3 Росією як продовжувачем традицій колишньої імперії кожне 
спростування ідеологічних міфів і маніпулятивних схем відіграє неабияке значення, оскільки ворожа пропагандистська система є потужною та ефективною щодо впливу на маргінальну частину населення України. У такому разі потрібно не лише виправдовуватися за нескоєне, але й активно атакувати, використовуючи логічні аргументи. Такими аргументами, наприклад, є викривання багатьох термінів державного устрою, що офіційно використовуються, але фактично $\epsilon$ лише стереотипами, а не суттєвими. Так, загальновживані терміни «радянський», «соціалістичний», «республіка», «союз», «федерація» стосовно колишньої держави та сучасної Росії насправді не відповідають своїй сутності. Якщо не пересічні громадяни, то публічні особи / службовці мусять це знати.

Аналіз останніх досліджень і публікацій. У межах політологічного й державницького розгляду ці питання аналізували українські вчені Б. Ажнюк [1], Л. Масенко [2] (у площині кореляції мовної ситуації в Україні та національної ідентичності іi громадян), Г. Могильницька [3] та П. Штепа [4] (у площині ідеологічного впливу Росії на український народ), кримськотатарський учений Н. Бекіров [5], який вивчав наслідки колишнього колоніалізму щодо державотворення. Проте ці наукові дослідження варто конкретизувати фактичними архівними матеріалами. Так, ми для цього використовуємо доповідь Йосифа Сталіна від 6 листопада 1941 року про сутність гітлерівського режиму.

Мета статті. Відповідно до вищенаведених аргументів актуальності метою цієї розвідки визначаємо аналіз термінів «фашизм», «шовінізм», «імперіалізм», «соціалізм» у площині їх використання в ідеологічних схемах із метою маніпулювання маргінальними народними масами.

Виклад основного матеріалу. Серед народної фразеології визначаються одиниці, що виявляють не лише семантично локальну сутність, але й багатоаспектність і неоднозначність. Так, скажімо, фразеологізм «із грязі в князі» має тривалу реальну рефлексію - ще від початку XX століття, коли демократичні віяння поширилися в Свропі, викорінивши зрештою самодержавство. Цей процес супроводжувався неабиякою агресивністю псевдореволюційних елементів, які в бомбово-револьверній атаці на певну державну особу (царя, міністра, генерала) не помічали довкола неї інших осіб, і навіть цивільних, зумовлюючи цим значні жертви. Так була сформована психологічна вседозволеність, що з часом призвела й до кризи православ'я, яке змогло б виправити таку небезпечну ситуацію, а не виправивши їі, саме потрапило під нещадну атаку більшовицької ідеологіі.

Соціальна свобода зумовила й деякі інші психологічні особливості подальшого життя, які виявилися актуальними й через сто років. Це, зокрема, такі пріоритети для «вільної» людини: власне житло, вища освіта для дітей і онуків, золоті прикраси тощо. Ці життєві чинники не є невід'ємними чи природними, i наші туристи часто дивуються 3 простоти іноземців в зовнішньому вигляді, неприв'язаності до одного місця проживання чи ставлення до побутової техніки й автомобілів як до повсякденних атрибутів, а не престижних речей. I лише зараз, коли чимало українців перманентно живуть i працюють у Європі, будучи 
свідками чи вже й адептами традицій цивілізованого світу, ті давні пріоритети поступово починають змінюватися. Зрештою власне житло та навчання на вищому рівні освіти буде непросто реалізувати матеріально. Утім, фразеологізм «із грязі в князі» має й суто психологічне підгрунтя, що передбачає просте бажання людини піднятися над сіризною довколишнього світу чи ближнього оточення.

Також відомим аспектом цієї проблеми є соціальна опозиція «село - місто», у межах якої відбувалося й відбувається чимало конфліктів, описаних у тій же художній літературі, коли саме селянин, потрапивши до міста, усілякими засобами утверджує своє становище та набутий статус. Зрештою більшість українців різного соціального статусу мають сільське походження, адже місто, населення якого збільшилося впродовж його історії на 100 відсотків, поповнювалося саме селянами. Проте переважна частина таких переселенців не має честолюбних планів, а тому стає до лав звичайних міщан - пересічних громадян, маргіналів.

Ще однією багатоаспектною фразеологічною одиницею варто визначити тезу «із хворої голови на здорову», що позначає відповідний психологічний прийом переведення уваги довколишніх із власної проблеми на чужу. Тобто сутність цього маніпулювання передбачає форму «з однієї голови на іншу», а ознака «хвора» надається вже за конкретною смисловою наповненістю ситуативною конотацією. Це актуально, скажімо, у ситуаціях побутових суперечок, коли одна людина звинувачує іншу в тому, що робить сама. Проте для нас більш важливими є політичні ситуації, що більш небезпечні, оскільки впливають не лише на геополітику, а й на ту масу людей, яких світова філософія називала «охлосом», «маргіналами», «люмпенами» тощо - хто не усвідомлює сутність подій і почутих термінів, вірячи словам різноманітних політичних маніпулянтів відповідно до певних власних мотивів. Зрозуміло, що мотив уже зумовлює відповідне сприйняття людини, яка буде в такому разі підлаштовувати матеріальні факти під потрібний їй результат, однак для нас важливою $\epsilon$ правильна аргументація такої колізії.

Для цього дослідження ми вибрали кілька термінів, серед яких, зокрема, «фашизм» визначається як такий, що пройшов шлях від статусу соціальної новації (20-ті роки XX сторіччя) до статусу негативно конотованого явища, який зберігається до нашого часу. Загалом зрозумілі його дефініції та практика використання порушені додатковими конотаціями, що вже не відповідають сутності цього поняття. Скажімо, так можуть назвати людину, яка просто виявляє жорстокість чи аморальність, причому не лише у справах, але й висловах. Відповідно так можна назвати й управлінський режим певного соціуму, що характеризується жорстокістю стосовно його членів.

Історично в часи зароджуваного протистояння радянської системи 3 германською (1930-ті роки) у пропагандистський дискурс було введено термінологічне словосполучення «націонал-фашист» (навіть у надалі 
забороненому «Російсько-українському словнику» А. Кримського і С. Єфремова воно дефінувалося), хоча словники того часу фіксували лише термін «фашизм» із похідними формами). Тобто атрибут «націонал» викликав також негативне ставлення в радянському суспільстві, i це було не що інше як намагання виробити більш широке за семантикою поняття, яким можна було б охопити будь-яке діяння, що не вкладається в радянський ідеологічний контекст. На той час вистачало й атрибута «фашист» для такого маркування. Так, Л. Масенко наводить приклад уживання цього слова для категоричної відозви «з уст простого народу»: анонімний донощик 1940 року пише про О. Довженка як прибічника «фашистського експресіонізму». Учена влучно називає це «доведенням масової свідомості до стану соціальної істерії» [2, с. 132].

Саме істеричний стан характеризує й окрему частину сучасного пострадянського суспільства, що вірить різноманітним популістським гаслам щодо «фашистів», «нацистів», «шовіністів» і т. ін., чіпляючи ці терміни, незважаючи на їх реальні дефініції, абсолютно голослівно до патріотичних сил. Натомість вони позначають інші сили - імперські, оскільки обов'язково передбачають авторитарне правління та зазіхання на території інших народів. Так, російські ідеологи, зокрема й сам Президент Російської «федерації» В. Путін, повісили відразу всі ці негативні ярлики на українських активістів і державників, незважаючи на будь-які словникові відповідності / невідповідності. Особливо дивним було називання 2014 року українського уряду «військовою хунтою», при тому що жоден фаховий військовий політичним активістом в Україні не був, натомість російський політичний актив був саме таким. Означене гасло викидалося в дискурс умисно - у розрахунку на ту названу нами вище масу маргіналів, які не в змозі проаналізувати навіть те, що президент Путін колишній працівник КДБ, який використовує традиційні технології політичної маніпуляції.

Як приклад гри термінологічними дефініціями ми наведемо висловлювання 3 виступу Сталіна на засіданні Московської ради депутатів 6 листопада 1941 року. Навіть якщо він читав складену кимось доповідь, то обов'язково мусив іi схвалити та зрозуміти. Проаналізуємо цей текст, послуговуючись перекладом Л. Масенко, щодо розумності та відповідності тогочасній (і сьогоденній) ситуації у світі.

Сталін зазначає: «Німецьких загарбників, тобто гітлерівців, у нас зазвичай називають фашистами. Гітлерівці, виявляється, уважають це неправильним і далі наполегливо називають себе «націонал-соціалістами». Відповідно німці хочуть переконати нас, що партія гітлерівців, партія німецьких загарбників, яка грабує Європу й організувала злочинний напад на нашу соціалістичну державу, $\epsilon$ партією соціалістичною. Чи це можливо? Що може бути спільного між соціалізмом і гітлерівськими озвірілими загарбниками, які чинять здирства та пригнічують народи Європи?» [6].

«Націонал-соціалізм», 3 етимологічного боку, передбачає домінанту 
соціального розвитку певної нації, натомість деякі інші фактично підлягають поработінню або й узагалі знищенню. Соціалізм же радянський отримує від сучасних учених префікс «псевдо», оскільки всі його ознаки (декларовані в Конституції) не відповідали дійсності. Не заглиблюючись у політичний та економічний аналіз, відзначаємо етимологічну невідповідність усіх складових словосполучення «союз радянських соціалістичних республік» тим деклараціям, яким вірили спочатку всі прогресивні сили світу: свобода, рівність, захист прав тощо. Насправді жорстка вертикаль влади нівелювала ці всі декларовані чесноти. I партія за допомогою каральних органів стала контролювати всі гілки влади, які лише формально були такими. Тобто термін «радянський» дійсності не відповідає, оскільки існує безальтернативна виборча система та завчасно визначені партійними органами депутати й рішення всіляких їхніх рад.

Відповідно термін «республіка» також $є$ формальним, адже роль тієї «публіки» (народу) в розподілі владних повноважень і народному господарстві надто незначна й полягає хіба що в можливості подати «сигнал» про діяльність якогось завмага чи завсклада. Так і кожна окрема «республіка» не мала жодної свободи в межах їх «союзу», виконуючи розпорядження центру. Коли вони отримали незалежність, то вся їхня промислова потужність стала сумнівною, оскільки більшість підприємств підлягали центральним міністерствам і часто були частиною військового комплексу. Тобто «союз» - також поняття фіктивне (знов-таки «псевдо»). Усі ж разом ці псевдотерміни нівелюють поняття «соціалістичний», адже у вертикалі «влада (партія) - соціум - людина» основні складові цього поняття стоять на другій позиції після влади. Аналогічною була ситуація в Російській імперії починаючи від Петра I, який упровадив загальну підвладність усіх іiї жителів його самодержавній владі.

Продовжуємо аналізувати Сталіна: «Чи можна вважати гітлерівців націоналістами? Нi, не можна. Насправді гітлерівці є нині не націоналістами, а імперіалістами. Поки гітлерівці займалися збиранням німецьких земель i возз'єднанням Рейнської області, Австрії тощо, їх можна було на відомих підставах вважати націоналістами. Та після того, як вони захопили чужі території й поневолили європейські нації - чехів, словаків... і стали домагатися світового панування, гітлерівська партія перестала бути націоналістичною, бо відтоді вона стала партією імперіалістичною, загарбницькою, гнобительською...» [6].:

Якщо відкинути публіцистичні / ідеологічні форми (на кшалт ознак «загарбницька», «гнобительська»), то наведені «вождем» аргументи доволі логічні: поки загарбання стосується колишніх етнічних земель, то воно хоч якось пояснюється. Натомість коли захоплюються історичні землі інших етносів, то це вже власне імперіалізм. Проте відповідно до предмета нашої розвідки цікавим $\epsilon$ інше: ці аргументи наводить особа - керівник держави, що упродовж кількох століть захоплювала («об’єднувала», анексувала) саме землі інших етносів угрофінських, тюркських, індіанських - узагалі без аргументації («одновірці», «слов’яни» тощо), i, зрозуміло, він ніколи б не згодився на називання своєї партії, 
країни

влади

такими

ознаками

«загарбницька»,

«гнобительська», «імперіалістична» чи й навіть «націоналістична». Тобто маємо аналізований нами феномен «з однієї [хворої] голови на іншу». При цьому це загарбання продовжувалося й надалі - захоплення територій прибалтійських народів (також не «одновірців» і не «слов'ян»), не кажучи вже про слов'ян i українців із білорусами, які ще й мають спільну рису «російськомовні». Ці мотиви передалися за владним спадком і наступникам сталінської держави - формації 3 назвою «Російська федерація», другий компонент якої також не відповідає дійсності, адже фактично всі ті федеральні суб'єкти жорстко підпорядковані одному - Росії.

Зрозуміло, що на противагу гітлерівським словам про потребу будь-якими засобами домогтися завоювання світу німцями, створивши «велику германську імперію», витіснивши й навіть знищивши «слов'янські народи - росіян, поляків, чехів, словаків, болгар, українців, білорусів» [6], постає головна комуністична ідея - «комунізм у всьому світі», яку, можливо, Гітлер і не дав можливості реалізувати, «віроломно» напавши на Радянський Союз, i яка продовжила існувати у 2-й половині XX сторіччя. Тобто будь-яка імперія, отримавши близькі території інших етносів, охоплена нестримним бажанням розширюватися й надалі, незважаючи на ідеологічне підгрунтя такого захоплення - «комунізм», «свобода народу», «релігія» тощо.

Аналізовану доповідь Гітлера складено 3 використанням маніпулятивних засобів, що передбачають уживання окремих негативно конотованих слів, які формували політичний дискурс ще від ленінського жовтневого путчу (починаючи 3 провідного - «контрреволюція», яким маркувалася будь-яка ворожа для режиму особа чи група осіб і, відповідно, аргументувалося їхнє вилучення із суспільства чи фізичне знищення). Це такі словосполучення, як «заклятые враги социализма», «злейшие реакционеры и черносотенцы», «реакционный режим», «попирают права рабочих», що серед маси народу викликали однозначно негативну реакцію, i не лише серед маргіналів, а й інтелігенції, - настільки повною мірою була створена формація «радянський народ» зі своїм менталітетом і системою духовних цінностей, зокрема сонму героїв та ідеологічних стереотипів. На той час таким негативним стереотипом була згадка про колишній царський режим, i Сталін використовує це, порівнюючи його з гітлерівським: «гітлерівський режим $\epsilon$ копією того реакційного режиму, що існував у Росії за царизму» 3 такою аргументацією: «порушують права робітників, права інтелігенції та права народів», «влаштовують середньовічні єврейські погроми», і все це роблять 3 радістю - «охотно» [6].

Названі «вождем» (ця лексема потребує окремої докладної розвідки щодо паралелей із примітивним язичницьким світом і відповідного авторитарного правління) ознаки, які об'єднують фашизм i самодержавство майже у всіх складових цих режимів, знаходимо в сучасних словникових визначеннях. Так, за тлумачним словником, фашизм - це «ідеологія культу сильної особистості, 
агресивного шовінізму та расизму» [7, с. 1530], а за словником іншомовних слів, він передбачає «ідеологію сильної особи, крайнього шовінізму і расизму», «терористичну диктатуру», «відвертий геноцид i етноцид, розв’язування загарбницьких воєн», «режим тоталітарного типу» [8, с. 565].

Як бачимо, на першому місці в означених дефініціях визначено безмежну владу однієї особи (тобто самодержавство), а далі вже як результати такого правління - тоталітарний режим усередині країни (для зміцнення диктаторської влади) та загарбання інших територій в ім’я своєї країни / нації (шовінізм), зрештою й утворення імперії (імперіалізм). Що ж до геноциду й етноциду, то без цих явищ такий режим не можливий, оскільки терористичний спосіб отримання влади передбачає знищення багатьох осіб, які не згодні з цим, і знищення певних народів (як фізичне, так і асимілятивне). Тобто всі названі негативні особливості властиві не лише фашизму як стереотипному об'єкту пропаганди, а й тому режимові, що цю пропаганду продукує. Іншими словами - німецький фашизм $\mathrm{i}$ «радянський» комунізм однаково й нарівні відзначалися цими ганебними ознаками. Сучасний же російський режим повернувся до тих традицій, винищуючи одночасно внутрішню політичну опозицію та захоплюючи поступово територію довкола себе за вищенаведеною схемою - від «одноязичної» / одновірної» до «слов'янської» й далі.

Ми є свідками першого 3 означених етапів - загарбання землі, де живуть найближчі «одновірці» й «одномовці» - українці. Сучасна імперська ідеологія базується на тезі про історичну «общность» - «русский мир», яку підтримують $\mathrm{i}$ чимало несвідомих українців. Проте будь-яка розумна людина бачить істотну відмінність між росіянами й українцями, яку П. Штепа пояснює навіть із генетичного боку: перші належать до «молодої мисливської» культурної групи, а другі - до «давньої рільничої» [Штепа]. Зазначимо, що росіяни набралися державницьких традицій і від Чингізхана, який репрезентує скотарську культуру. Тому наші народи помітно відрізняються і генетично, і духовно. Декларована ж Путіним «спільність» оформлювалася впродовж саме радянського періоду (до того українські губернії вважалися неросійськими), і робилося це більшою мірою через утвердження російської мови в усіх сферах життя радянського народу, на що працювала ціла система ідеологічних засобів. Наразі «російськомовність» $\epsilon$ головним чинником імперської ідеологї та, незважаючи на зазначені вище генетичні й духовні відмінності, найслабшою ланкою в українській політиці захисту від російських зазіхань.

Висновки. Отже, усі зазначені термінологічні колізіі, що виявляють хибні ідеологічні стереотипи, наявні через один мотив, який є актуальним упродовж багатьох століть, - маніпулювання власним народом. У площині ж наведеної на початку нашої розвідки приказки «із хворої голови на здорову» таке маніпулювання відбувається через звинувачення в цьому політичного супротивника. У такому разі слова Сталіна «і якщо ці шалені імперіалісти $\mathrm{i}$ найлютіші реакціонери все ще продовжують рядитися в тогу «націоналістів» $\mathrm{i}$ 
«соціалістів», то це вони роблять для того, щоб одурити народ, одурити простаків i прикрити прапором «націоналізму» i «соціалізму» свою розбійницьку імперіалістичну сутність» [6] потрібно сприймати як одурення «простаків» із власного, підвладного йому народу. У контексті сучасної Росії про це саме говорять місцеві правозахисники, яких влада безсоромно знищує.

Найефективніше такі стереотипні звинувачення з боку самих імперіалістів спростовуються (викриваються) риторичними запереченнями. Так, етнос (нація), який не мав ніколи тривалої державності, завжди перебував на своїй території, був під владою інших держав / імперій, не може апріорі бути шовіністом, фашистом або імперіалістом. У часи ж нетривалої державності цей народ також не виявляв таких настроїв, оскільки не мав навіть військової сили для захисту власної території. Водночас виявлялися його демократичні пріоритети, а тому терміни «республіка», «унітарія», «ліберальність» стосовно українців як нації повною мірою відповідають своїй сутності. Наразі ж такий народ просто прагне іншого життя - у колі європейських цивілізаційних держав.

\section{Лimepamypa:}

1. Ажнюк Б. Мовна політика і єдність нації / Б. Ажнюк. Мовознавство: [доп. та повідомл. IV Міжнар. конгр. україністів]. К.: Пульсари, 2002. - С. 202-207.

2. Масенко Л. Мова радянського тоталітаризму. Київ:ТОВ «Вид-во «Кліо», 2017.- 240с.

3. Могильницька Г. Міфотворчість як обгрунтування історичного мародерства. Бровари: Українська ідея, 2009. - 184 с.

4. Штепа П. Московство, його походження, зміст, форми й історична тяглість. Ч. 1. Торонто: Вид. С. Стасишина, 1968. - 345 с.

5. Бекіров Н. В. Право на самовизначення як соціокультурний принцип епохи подолання наслідків колоніалізму. Теорія та практика державного управління і місцевого самоврядування. 2016. - № 2. - C. 12-13. URL: http://www.irbis-nbuv.gov.ua

6. Сталин И. В. 24-я годовщина Великой Октябрьской социалистической революции. Доклад на торжественном заседании Московского совета депутатов трудящихся с партийными и общественными организациями г. Москвы 6 ноября 1941 года. URL: https://www.marxists.org/russkij/stalin/t15/t15_13.htm

7. Великий тлумачний словник сучасної української мови / укл. і гол ред. В.Т. Бусел. Київ; Ірпінь : ВТФ «Перун», 2005. - 1728 с.

8. Бибик С. П., Сюта Г. М. Словник іншомовних слів: тлумачення, словотворення та слововживання / за ред. С.Я. Ярмоленко. Харків : Фоліо, 2006. - 623 с.

\section{References:}

1. Azhnyuk, B. (2002). Movna polityka i yednist' natsiyi [Language policy and unity of the nation]. Movoznavstvo: dopovidi ta povidomlennya IV Mizhnarodnoho konhresu ukrayinistiv [Linguistics: reports and announcements of the IV International Congress of Ukrainians]. Kyiv: Pul'sary (pp. 202-207) [in Ukrainian].

2. Masenko, L. (2017). Mova radyans'koho totalitaryzmu [The language of Soviet totalitarianism]. Kyiv: TOV «Vyd-vo «Klio» [in Ukrainian].

3. Mohyl'nyts'ka H. (2009). Mifotvorchist' yak obgruntuvannya istorychnoho maroderstva [Myth-making as a justification for historical looting]. Brovary: Ukrayins'ka ideya [in Ukrainian]. 
4. Shtepa, P. (1968). Moskovstvo, yoho pokhodzhennya, zmist, formy y istorychna tyahlist' [Moscow, its origin, content, forms and historical longevity] (Vol. 1). Toronto: Vyd. S. Stasyshyna [in Ukrainian].

5. Bekirov, N. V. (2016). Pravo na samovyznachennya yak sotsiokul'turnyy pryntsyp epokhy podolannya naslidkiv kolonializmu [The right to self-determination as a socio-cultural principle of the era of overcoming the consequences of colonialism]. Teoriya ta praktyka derzhavnoho upravlinnya $i$ mistsevoho samovryaduvannya [Theory and practice of public administration and local selfgovernment] (Vol. 2), (pp. 12-13). URL: http://www.irbis-nbuv.gov.ua [in Ukrainian].

6. Stalyn, Y.V. (2021). 24-ya hodovshchyna Velykoy Oktyabr'skoy sotsyalystycheskoy revolyutsyy. Doklad na torzhestvennom zasedanyy Moskovskoho soveta deputatov trudyashchykhsya s partyynymy $y$ obshchestvennymy orhanyzatsyyamy h. Moskvy 6 noyabrya 1941 hoda [24th anniversary of the Great October Socialist Revolution. Report at a solemn meeting of the Moscow Council of Workers' Deputies with party and public organizations in Moscow on November 6, 1941]. URL: https://www.marxists.org/russkij/stalin/t15/t15_13.htm [in Ukrainian].

7. Busel, V.T. (Eds). (2005). Velykyy tlumachnyy slovnyk suchasnoyi ukrayins'koyi movy [Large explanatory dictionary of the modern Ukrainian language]. Kyiv; Irpin' : VTF «Perun» [in Ukrainian].

8. Bybyk, S. P., Syuta, H. M. (2006). Slovnyk inshomovnykh sliv: tlumachennya, slovotvorennya ta slovovzhyvannya [Dictionary of foreign words: interpretation, word formation and word usage]. Kharkiv : Folio [in Ukrainian]. 